\title{
The occurrence of the herbicide Dalapon (2,2-Dichloropropionate) in potable water as a disinfection byproduct
}

\author{
Darryl W. Hawker", Janet L. Cumming ${ }^{b}$, Andrew Watkinson ${ }^{c}$ and Michael \\ E. Bartkow ${ }^{c}$ \\ ${ }^{a}$ School of Environment, Griffith University, Nathan, QLD 4111, Australia \\ ${ }^{b}$ Population Health Branch, The Chief Health Officer Division, Queensland Health, \\ Herston, Qld 4006, Australia \\ ${ }^{c}$ Queensland Bulk Water Supply Authority (trading as Seqwater), Brisbane, QLD 4000, \\ Australia
}

(Received

; final version received

\begin{abstract}
Salts of 2,2-dichloropropionic acid, such as dalapon, are well known as herbicides and are regulated as such in potable water in Australia and elsewhere. It is also an identified disinfection by-product (DBP), but little is known about the compound's formation and typical levels from this source. This work presents results from a sampling campaign where 2,2-dichloropropionate was found at levels between 0.1 and $0.5 \mu \mathrm{g} \mathrm{l^{-1 }}$ in potable water samples from a major treatment plant in South East Queensland, Australia. However, levels were below the analytical detection limit in the immediate source water for the plant. This plant uses chlorine as a primary disinfectant and monochloramine as a secondary disinfectant. Temporal trends in 2,2-dichloropropionate observed in treated water during sampling mirrored those of trihalomethanes albeit at concentrations at least an order of magnitude less. This suggests that the occurrence here is due to in-situ formation as aBP. Observation of this compound in treated potable water at levels such as found in this work may therefore not always be due to herbicide contamination of source water that is incompletely removed during treatment and in such circumstances it is best considered and managed as a DBP.
\end{abstract}

\section{Environmental Impact}

The quality of drinking water is routinely monitored under a risk management process to ensure compliance with appropriate regulatory guidelines and thresholds. In chlorinated water, disinfection by-products such as chloroform are commonly detected at relatively low levels. Dalapon is a herbicide that is widely used in Australia and elsewhere. It is not widely known that it can also be a disinfection by-product. Here we provide evidence that its occurrence in treated drinking water from South East Queensland, Australia is likely due to in-situ formation in the treatment plant. Detection of this compound in drinking 
water may not always be due to its use as a herbicide however the assessment of its presence and the risk to public health would remain the same.

\section{Introduction}

The public health benefits of disinfection of water for potable use are well recognised. The process of disinfection aims to kill all bacterial pathogens and greatly reduce the numbers of viable viral and many protozoan pathogens and is critical for the safety of potable water. ${ }^{1}$ Common chemical disinfectants include chlorine, monochloramine, chlorine dioxide and ozone. These act as oxidants and can react with solutes such as dissolved organic matter and inorganic species such as bromide and iodide present in source water to produce disinfection by-products (DBPs). ${ }^{2}$ Chlorine has been employed as a disinfectant for over one hundred years and forms hundreds of different DBPs including trihalomethanes (THMs), haloacetic Acids (HAAs) and N-nitrosamines. The THMs have been shown to be carcinogenic in test animals and on a mass basis are largest class of DBP typically produced with chlorine. ${ }^{3,4}$ Therefore, levels of THMs are regulated in potable water, along with HAAs. The potential public health risks of other reported DBPs such as halonitriles and halonitroalkanes are, according to Woo et al. ${ }^{5}$, largely unknown. Little is known of their concentrations and they are unregulated. In fact, the majority of DBPs present in potable water have yet to be chemically characterised and their public health risks are similarly unknown.,

The organochlorine 2,2-dichloropropionic acid has been reported to be a DBP or potential DBP. ${ }^{5,6}$ It is also an analyte in EPA Method 552.2 that is otherwise concerned with the quantification of HAAs in potable water. ${ }^{6}$ In this method, the compound is 
referred to as a chlorinated herbicide. ${ }^{7}$ In potable water it would exist as the conjugate base 2,2-dichloropropionate given its pKa value of approximately $1.8 .^{8}$

Richardson et $a l^{3}$ have identified this compound in potable water when chlorine or chloramines were employed as a secondary disinfectant following ozonation. There are also references to its detection in product water from potable water treatment plants, however source water quality is not mentioned. ${ }^{9}$ This may be important because this compound is also a herbicide known as dalapon or 2,2-DPA. Dalapon is regarded as a general use herbicide by the USEPA ${ }^{10}$ and its presence in potable water as a herbicide is regulated in a number of jurisdictions. In the USA, its maximum contaminant level is 0.2 $\mathrm{mg} \mathrm{l}^{-1}$ (http:/www.epa.gov/safewater/contaminants/basicinformation/dalapon.html). In Australia, 2,2-dichloropropionate salts are currently registered by the Australian Pesticides and Veterinary Medicines Authority as a herbicide. ${ }^{11}$ Based on the Australian Drinking Water Guidelines, the compound has a health value in potable water of $0.5 \mathrm{mg}$ $\mathrm{I}^{-1}$. Acute toxicity data suggest a low order of toxicity to mammals and the USEPA has established a Lifetime Health Advisory of $200 \mu \mathrm{g} \mathrm{l}^{-1}$ for dalapon in drinking water, but in doing so, classifies the compound as a herbicide. ${ }^{10,12}$

From a water treatment management response perspective it is of interest to establish whether the appearance of this compound in product water from potable water treatment plants is due to its presence in source water, formation as a DBP or indeed whether both pathways are operable. Hereafter in this work, the compound will be referred to as 2,2-dichloropropionate rather than dalapon, 2,2-DPA or other synonyms or trade names to recognise that its occurrence in treated potable water may not always be due to herbicide contamination of source water. 
The major potable water treatment plant in South-East Queensland at Mount Crosby has a nominal capacity of $750 \mathrm{Ml} \mathrm{d}^{-1}$ and draws its source water from the MidBrisbane River ${ }^{13}$ below Wivenhoe Dam. Water is released from Wivenhoe Dam, $60 \mathrm{~km}$ upstream, for this purpose and water from tributaries draining agricultural land upstream is also present in the source water. The plant employs chlorine as a primary disinfectant and monochloramine as a secondary disinfectant.

The aims of this work are firstly to quantify levels of 2,2-dichloropropionate in the source water and treated water from Mount Crosby and also investigate any relationship between trends in levels in treated potable water and DBPs such as THMs with a view to establishing whether any occurrence is due to in situ formation as a DBP.

\section{Materials and Methods}

\subsection{Sample Collection}

Sampling was undertaken at two sites, the Mt Crosby Weir and from the Mt Crosby West Bank Water Treatment Plant (post treatment). Treated water was sampled once per week for 13 weeks. Samples were collected from the raw source water at Mt Crosby weir at weeks 1,5 and 9 .

All samples were collected in compliance with the DERM (formerly QEPA) Water Quality Sampling Manual, ${ }^{14}$ relevant Australian Standards (AS5667: 1998) and the Standard Methods for the Examination of Water and Wastewater (APHA) Manual. ${ }^{15}$ Samples were collected in 11 solvent washed amber glass bottles rinsed thoroughly with site water. Following collection, samples were transported to the laboratory on ice and in the dark. Source water samples were collected by composite of 3 samples taken with a 
$3 \mathrm{~m}$-integrated (surface to $3 \mathrm{~m}$ depth) sampling pole. Treated water samples were taken at the post-treatment sampling tap prior to distribution using a 201 composite bucket over 5 minutes. Field blanks were collected using reverse osmosis water subjected to the same sampling process as described above.

All samples were analysed at Queensland Health Forensic and Scientific Services Laboratories in accordance with National Association of Testing Authorities (NATA) approved methods and procedures for 2,2-dichloropropionate and DBPs as described below. NATA is Australia's national laboratory accreditation scheme recognising facilities competent in specific types of analysis.

\subsection{Chemicals and reagents}

Water was deionised and passed through reverse osmosis prior to carbon filtration. Methyl t-butyl ether was purchased from Merck LiChrosolv and was GC grade $(>99.8 \%$ purity). High purity methanol was used that was demonstrated to be free from interferences prior to use. Anhydrous sodium sulfate was heated to $400{ }^{\circ} \mathrm{C}$ for up to 4 hours or at $130^{\circ} \mathrm{C}$ overnight before use. Sodium bicarbonate was a BDH Analytical reagent.

\subsection{Analytical Methods}

\section{2,2-Dichloropropionate}

A portion of the water sample $(40 \mathrm{ml})$ was acidified to $\mathrm{pH} 2$ with $\mathrm{HCl}$ prior to extraction by SPE using a StrataX SPE $200 \mathrm{mg} / 3 \mathrm{~cm}^{3}$ column (Phenomenex, Torrance, CA). The analyte was eluted with methanol: acetonitrile: acetone $(1: 1: 1)$ and the volume of the solution reduced to $0.4 \mathrm{ml}$. The sample extracts were analysed by HPLC/tandem Mass Spectrometry (HPLC-MS-MS). Separation was achieved using a Shimadzu Prominence 
HPLC system (Shimadzu Corp., Kyoto, Japan) with a $3 \mu \mathrm{m}$ particle size $150 \times 2 \mathrm{~mm}$ Luna $\mathrm{C}_{18}$ column (Phenomenex, Torrance, $\mathrm{CA}$ ) at $45^{\circ} \mathrm{C}$, and a mobile phase flow rate of $0.35 \mathrm{ml} \mathrm{min}^{-1}$. The HPLC gradient gradient starting at $15 \% \mathrm{~B}$ for 0.3 minutes, ramped to $100 \% \mathrm{~B}$ in 10 minutes, held for 4 minute and then to $15 \% \mathrm{~B}$ in 0.2 minutes and equilibrated for 4 minutes. $(A=1 \%$ acetonitrile/99\% HPLC grade water, $B=95 \%$ acetonitrile $/ 5 \%$ HPLC grade water both containing $0.1 \%$ formic acid). The HPLC was interfaced to an $\mathrm{AB} / \mathrm{Sciex} \mathrm{API} 4000 \mathrm{Q}$ mass spectrometer equipped with an electrospray (TurboV) interface (MDS Sciex, Concord, Ont., Canada) with each sample extract analysed in negative ion multiple reaction monitoring mode. Analyte concentrations were determined using the internal standard method and compared to a four-point calibration using standard concentrations from 5 to $100 \mu \mathrm{gl}^{-1}$.

Identification was confirmed by retention time and by comparing transition intensity ratios between the sample and an appropriate concentration standard from the same run. Samples were only reported as positive if the two transitions were present, retention time was within 0.15 minutes of the standard and the relative intensity of the confirmation transition was within $20 \%$ of the expected value.

Using an $8 \mu$ injection volume, the limit of detection for this method was typically less than $2 \mathrm{ng} \mathrm{l}^{-1}$, with a reporting limit of $10 \mathrm{ng}^{-1}$. Response was linear to at least $1000 \mathrm{ng} 1^{-1}$ and spike recoveries were typically between 50 and $90 \%$.

\section{THMs}

Water samples were analysed for THMs by purge-and-trap gas chromatography-mass spectrometry that has become an accepted method for THMs in water. ${ }^{16}$ The purge-andtrap system was a Tekmar Velocity XPT Sample Concentrator (Teldyne Tekmar 
Instruments, Ohio, USA) fitted with a Vocarb 3000 trap. The sample was introduced into the purge-and-trap system by an EST 8100 Purge and Trap Autosampler (EST

Analytical, Fairfield, Ohio, USA). Operating conditions for both autosampler and sample concentrator are summarised in the Electronic Supplementary Information. The trap was heated to $250^{\circ} \mathrm{C}$ for $0.5 \mathrm{~min}$, thermally desorbing the analytes that were then transferred to the $\mathrm{GC}$ at $250 \mathrm{ml} \mathrm{min}{ }^{-1}$. The GC was fitted with a Zebron ZB-624 capillary column (20 $\mathrm{m} \times 0.18 \mathrm{~mm} \times 1.0 \mu \mathrm{m})$ operated in split mode $(50: 1)$. The temperature program was holding for $2 \mathrm{~min}$ at $40^{\circ} \mathrm{C}$, then heating at $10^{\circ} \mathrm{C} \mathrm{min}^{-1}$ up to $200^{\circ} \mathrm{C}$.

The internal standards were fluorobenzene, chlorobenzene-d5 and 1,4dichlorobenzene-d4. QC check standards were prepared at concentrations of 10,50 and $100 \mathrm{ng} \mathrm{ml}^{-1}$ in water. Limit of detection was calculated as three times the standard deviation of data from ten replicate samples at $1 \mathrm{ng} \mathrm{ml}^{-1}$. The limit of reporting was calculated as three time the limit of detection. A typical limit of reporting was $1 \mu \mathrm{g} \mathrm{l}^{-1}$. HAAs

Haloacetic acids were extracted from aqueous samples by methyl t-butyl ether after addition of sulphuric acid and anhydrous sodium sulfate. To a $30 \mathrm{ml}$ water sample was added $2.0 \mathrm{ml}$ concentrated sulphuric acid, $12 \mathrm{~g}$ anhydrous sodium sulfate and $3.0 \mathrm{ml}$ methyl t-butyl ether. Also added at this time was $100 \mu 1$ of the surrogate standard (2,2dibromopropionic acid $100 \mu \mathrm{g} \mathrm{ml}^{-1}$ ). The HAAs in the methyl t-butyl ether solution were methylated at $60{ }^{\circ} \mathrm{C}$ using $10 \% \mathrm{v} / \mathrm{v}$ sulphuric acid in methanol, followed by neutralisation $\left(\mathrm{NaHCO}_{3}\right)$. The upper layer (methyl t-butyl ether) was separated and analysed by GCECD. 1,2,3-Trichloropropane was used as an external standard. 
The GC (HP 5890) was fitted with a DB-1701 capillary column (15 $\mathrm{m} \times 0.32 \mathrm{~mm}$ $\mathrm{x} 0.25 \mu \mathrm{m}$ ) and the temperature program was $50^{\circ} \mathrm{C}$ for $6 \mathrm{~min}$, then $2{ }^{\circ} \mathrm{C} \mathrm{min}^{-1}$ up to 75 ${ }^{\circ} \mathrm{C}$, hold for $5 \mathrm{~min}$, then $40^{\circ} \mathrm{C} \min -1$ up to $240^{\circ} \mathrm{C}$ and hold for $5 \mathrm{~min}$. The ECD temperature was $300^{\circ} \mathrm{C}$.

The method was linear up to $200 \mu \mathrm{g} \mathrm{l}^{-1}$ for each HAA component and the normal limit of reporting was $10 \mu \mathrm{g}^{-1}$ for each HAA component.

\section{Results and Discussion}

Levels of 2,2-dichloropropionate in potable water from the Mount Crosby West Bank Treatment Plant varied between 0.1 and $0.5 \mu \mathrm{g}^{-1}$ during the 13-week sampling campaign. There were no treated water samples in which the compound was not found. This is shown in Figure 1 where, for comparison, levels of THMs concurrently found are displayed. The levels of THMs, except for bromoform, are approximately two orders of magnitude greater than that for 2,2-dichloropropionate. The occurrence of THMs in plants that employ chlorine as a primary disinfectant and monochloramine as a secondary disinfectant is certainly not unusual, nor are the concentrations found and presented in Figure 1. ${ }^{4,17}$ However, there is relatively little quantitative data for comparison with regard to the occurrence of 2,2-dichloropropionate. It has been identified as a possible $\mathrm{DBP},{ }^{3,6}$ and the compound has previously been found in potable water samples from Maryland and Ohio, USA at levels of approximately 0.3 and 0.8 to $4.5 \mu \mathrm{g}{ }^{-1}$ respectively. ${ }^{9,18}$ In both cases however, its presence was ascribed to herbicide contamination of source water. Levels of total halopropionic acids, categorised as DBPs, in potable water from Japan, were less than approximately $2 \mu \mathrm{g} 1^{-1} .^{19}$ 


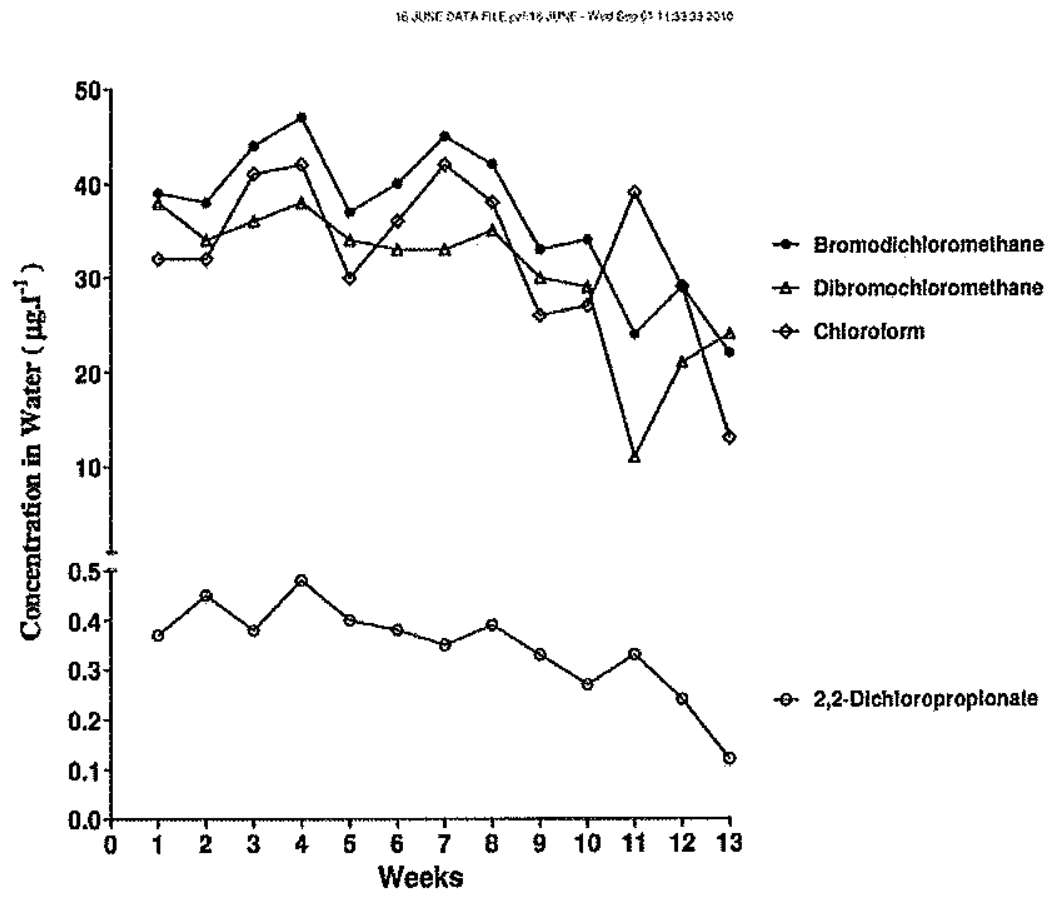

Fig. 1 Concentrations of 2,2-Dichloropropionate and THMs $\left(\mu \mathrm{g}^{-1}\right)$ in treated potable water samples collected weekly for 13 consecutive weeks.

In weeks 1,5 and 9 of the sampling campaign, the weekly sample of potable water was supplemented by a sample of raw water in the weir from which the source water to be treated is drawn. On each occasion, the concentration of 2,2dichloropropionate was below the reporting limit of $0.01 \mu \mathrm{g} \mathrm{I}^{-1}$ as shown in Table 1. In addition, weekly baseflow sampling at 4 sites upstream for 13 weeks failed to detect 2,2dichloropropionate. ${ }^{20}$ The compound is employed as herbicide in Australia and possibly in the catchment area of the source water for Mount Crosby Water Treatment Plant. However, in waterways, 2,2-dichloropropionate is lost largely by microbial degradation and phototransformation with the microbial pathway usually the most important..$^{12,21} \mathrm{~A}$ biodegradation half-life value for water estimated using the BIOWIN 3 model in 
BIOWIN $^{\top M}$ v4.1 is weeks to months. ${ }^{22}$ The relative lability of 2,2-dichloropropionate suggests that the observed negligible levels in the immediate source water at Mount Crosby as well as upstream are still consistent with its possible use as a herbicide.

Table 1 Concentration of 2,2-Dichloropropionate in matched samples from source and treated water $\left(\mu \mathrm{g} \mathrm{l}^{-1}\right)$

\begin{tabular}{lccc}
\multicolumn{1}{c}{ Date } & Week 1 & Week 5 & Week 9 \\
Site & & & \\
Mt Crosby & & & \\
Weir & $<0.01$ & $<0.01$ & $<0.01$ \\
Treated Water & 0.37 & 0.40 & 0.33 \\
Field blank & $<0.01$ & $<0.01$ & $<0.01$
\end{tabular}

If the occurrence of 2,2-dichloropropionate in treated potable water is not due to contamination present in source water, it may be as a result of in situ formation as a DBP. To investigate this, Spearman's rank correlation was used with THM and 2,2dichoropropionate concentrations. This indicates the presence and strength of a monotonic association between two variables and does not assume a particular distribution in variable data. Spearman's Rank Correlation Coefficients are presented in Table 2 along with, for comparison, those between the various THMs themselves. Coefficients significant at the $\mathrm{P}<0.01$ level are identified by an asterisk. ${ }^{23}$ Associations between 2,2-dichloropropionate and individual THMs appear to be at least as significant as those between different THMs. That is, when levels of THMS are relatively high, so are levels of 2,2-dichloropropionate and vice versa. This, together with the lack of 2,2dichloropropionate in source water is good evidence that the occurrence of this compound in this situation is due to its formation as a DBP. 
Table 2 Spearman's rank correlation between 2,2-Dichloropropionate and THMs and between various THMs themselves in treated water samples from the 13-week sampling program. Coefficients significant at the $\mathrm{P}<0.01$ level are denoted by an asterisk. ${ }^{23}$

DBP 1

Chloroform

Bromodichloromethane

Dibromochloromethane

Bromoform

Chloroform

Chloroform

Chloroform

Bromodichloromethane

Bromodichloromethane

Dibromochloromethane

\section{DBP 2}

2,2-Dichloropropionate

2,2-Dichloropropionate

2,2-Dichloropropionate

2,2-Dichloropropionate

Bromodichloromethane

Dibromochloromethane

Bromoform

Dibromochloromethane

Bromoform

Bromoform

\section{Coefficient}

0.57

$0.71^{*}$

$0.79 *$

0.61

$0.78 *$

0.47

$-0.10$

$0.80^{*}$

0.31

$0.75^{*}$

The precursors of halogenated DBPs are generally thought to be dissolved organic matter (DOM) and halide ions, along with chemical disinfectants such as chlorine and monochloramine. ${ }^{17,24}$ The mechanism of formation of 2,2-dichloropropionate as a DBP therefore also presumably involves DOM. THMs and a second major group of DBPs, HAAs are formed in this way. Krasner et al. ${ }^{4}$ note that the HAAs were the second largest class of DBP found, on a mass basis, in a survey of US potable water. Some of the HAAs are regulated due to potential adverse health effects. ${ }^{2,6}$

Concentrations of HAAs found in potable water at Mount Crosby, along with Spearman's Rank Correlation Coefficients for association between 2,2-

dichloropropionate and individual HAAs are shown in the Electronic Supplementary Information. The HAA concentrations varied between the appropriate analytical detection limit and $27 \mu \mathrm{g} \mathrm{l}^{-1}$, with this range intermediate between those of the THMs and 2,2dichloropropionate. The correlation coefficients are in general smaller, some considerably so, than those in Table 1 representing association between 2,2- 
dichloropropionate and THMs. Although DBP formation mechanisms are somewhat complex, this may suggest there is a greater difference between those of HAAs and 2,2dichloropropionate than between THMs and 2,2-dichloropropionate.

Resorcinol or m-dihydroxybenzene type structures in DOM have been shown to produce THMs $^{25}$ and also HAAs. ${ }^{26,27}$ Aliphatic type structures are also possible precursors $^{28}$ producing largely THMs. ${ }^{29}$ The haloform reaction is a good example of this. However, the mechanisms of such reactions appear inconsistent with the production of 2,2-dichloropropionate.

Using operationally defined DOM fractions, Marhaba and Van ${ }^{29}$ found a hydrophilic acid fraction to be the most reactive THM precursor, but the neutral hydrophobic fraction to be the most important for HAAs. Boucharat et al.$^{30}$ point out that carboxylic acids represent $5-8 \%$ of the DOM identified in natural waters. Direct chlorination of propionic acid in the presence of catalysts such as acids and $\mathrm{FeCl}_{3}$ has been shown to afford 2,2-dichloropropionic acid, amongst other isomers. ${ }^{31}$ Although the conditions are somewhat different to those existing in potable water treatment processes, this is a possible pathway for the in situ production of 2,2-dichloropropionate as a DBP.

\section{Conclusion}

The organochlorine 2,2-dichloropropionate is well known as a herbicide, but it is also a little known DBP. Typical levels when formed as a DBP and their relationship of those to other DBPs are virtually unknown. Concentrations between 0.1 and $0.5 \mu \mathrm{g}^{-1}$ were found in all treated potable water samples from a major plant in South East Queensland, Australia during a 13-week sampling campaign. This plant practices chlorination followed by chloramination. During this period, 2,2-dichloropropionate could not be 
detected in the immediate source water for the plant, nor at four sites upstream of the plant. This, together with the fact that temporal concentration trends during the sampling period mirrored those of THMs, but at least an order of magnitude lower, suggest in-situ formation as a DBP. In this situation then, the compound should be regarded as a DBP, rather than a herbicide contaminant. The occurrence of 2,2-dichloropropionate in other potable waters elsewhere, and at similar levels, may also be indicative of formation as a DBP, rather than necessarily contamination of source water from herbicide use. The limited association between trends in 2,2-dichloropropionate levels in the potable water investigated here and HAA levels may provide some insight into it mechanism of formation as a DBP.

\section{Acknowledgements}

This work was supported by Queensland Bulk Water Supply Authority (trading as Seqwater), Brisbane, QLD 4000, Australia. The authors thank Sarah Lennox of CSIRO for assistance with statistical analysis, the Seqwater Catchment Water Quality Monitoring Team, particularly Catherine Moore, for sample collection and provision of water quality data and Steve Carter and Simon Christen of Forensic and Scientific Services, Clinical and Statewide Services Division, Queensland Health for analysis of water samples.

\section{References}

1 ADWG 2004. Australian Drinking Water Guidelines 6, NHMRC, ARMCANZ, Commonwealth of Australia.

2 M.J. Plewa, E.D.Wagner, S.D. Richardson, A.D.Thruston Jr., Y-T. Woo and A.B. McKague, Environ. Sci. Technol., 2004, 38, 4713-4722.

3 S.D. Richardson, A.D Thruston Jr., T.V.Caughran, P.H. Chen, T.W. Collette, K.M. Schenck, B.W. Lykins Jr., C. Rav-Acha and V. Glezer, 2000, Water Air Soil Poll., 
123, 95-102.

4 S.W. Krasner, H.S.Weinberg, S.D.Richardson, S.J. Pastor, R. Chinn, M.J. Sclimenti, G.D. Onstad and A.D. Thruston Jr., Environ. Sci. Technol., 2006, 40, 7175-7185.

5 Y-T. Woo, D.Lai, J.L.McLain, M.K. Manibusan and V. Dellarco, 2002, Environ. Health Persp., 110, 75-87.

6 Y. Xie, Water Research, 2002, 35, 1599-1602.

7 USEPA 1995. Method 552.2: determination of haloacetic acids and dalapon in drinking water by liquid-liquid extraction, derivatization and gas chromatography with electron capture detection. Environmental Monitoring and System Laboratory, Cincinnati, $\mathrm{OH}$.

8 G. Kyriaskopoulos and D. Doulia, Sep. Purif. Rev., 2006, 35(3), 97-191.

9 Maryland Department of Environment, 2006, Source Water Assessment for Conowingo Water Treatment Plant,Darlington, Maryland.

(www.mde.state.md.us/.../Conowingo $\% 20$ Water $\% 20$ Treatment $\% 20$ Plant.pdf) Accessed June 2010.

10 USEPA, 2002, Final Drinking Water Criteria Document for Dalapon. (nepis.epa.gov/Exe/ZyPURL.cgi?Dockey $=901$ H0200... - United States). Accessed June 2010.

11 APVMA 2010, Australian Pesticide and Veterinary Medicine Authority, Canberra. (http://www.apvma.gov.au/) Accessed June 2010.

12 EXTOXNET, 1996, Extension Toxicology Network Pesticide Information Profiles. (http://extoxnet.orst.edu/pips/dalapon.htm) Accessed June 2010.

13 Queensland Water Commission, 2008, Purified recycled water for drinking: The technical issues. (T. Gardner, C. Yeates and R. Shaw, Eds.) http://www.qwc.gld.gov.au/Technical+issues+paper (accessed June 2010), Queensland Government, Brisbane, Australia.

14 DERM (formerly QEPA), 1999, Water Quality Sampling Manual, third ed. Queensland Government, Brisbane.

15 APHA-A WWA-WCPE, Standard methods for the examination of water and wastewater, American Public Health Association, Washington, DC, $20^{\text {th }}$ edn, 1998.

16 F. Ruiz-Bevia, M.J. Fernandez-Torres and M.P. Blasco-Alemany, Analytica Chimica Acta, 2009, 632, 304-314.

17 B.Chen and P. Westerhoff, Water Research 2010, In Press.

18 Ohio EPA, 2009, Drinking water quality sampling to support the Ohio Department of Health, Childhood Cancer Investigation, City of Clyde and surrounding townships. (www.epa.state.oh.us/.../clyde/Clyde WQ Complete Report 050409.pdf). Accessed June 2010.

19 Y. Takahashi and M. Morita, Kankyo Kagaku, 1998, 8, 455-464.

20 Seqwater, 2009, Seqwater Verification Monitoring Program: Final Report. Submission to the Queensland Water Commission.

21 D.W. Hawker, J. L. Cumming, P. A. Neale, M. E. Bartkow and B. I. Escher, Water Research, 2010, Submitted.

22 USEPA (2008) EPISuite Exposure Assessment Tools and Models. (http://www.epa.gov/opptintr/exposure/pubs/episuite.htm) Accessed June 2010.

23 P.H. Ramsey, J. Educ. Behav. Stat., 1989, 14, 245-253.

24 G. Hua and D.A. Reckhow, Journal AWWA, 2008, 100, 82-95. 
25 H. Gallard and U. von Genten, Water Research, 2002, 36, 65-74.

26 E.R.V. Dickenson, R.S. Summers, J-P. Croué and H. Gallard, Environ. Sci. Technol., 2008, 42, 3226-3233.

27 M.L. Pomes, W.R. Green, E.M. Thurman, W.H. Orem, and H.E. Lerch, Journal $A W W A, 1999,91,103-115$.

28 W.A. Arnold, J. Bolotin, U von Gunten and T.B. Hofstetter, Environ. Sci. Technol., $2008,42,7778-7785$.

29 T.F. Marhaba and D. Van, J. Hazard. Mater., 2000, A74, 133-147.

30 C. Boucharat, V. Desauziers, and P. Le Cloirec, Talanta 1998, 47(2), 311-323.

31 Y.Ogata and K.Matsuyama, Tetrahedron, 1970, 26, 5929-5937. 


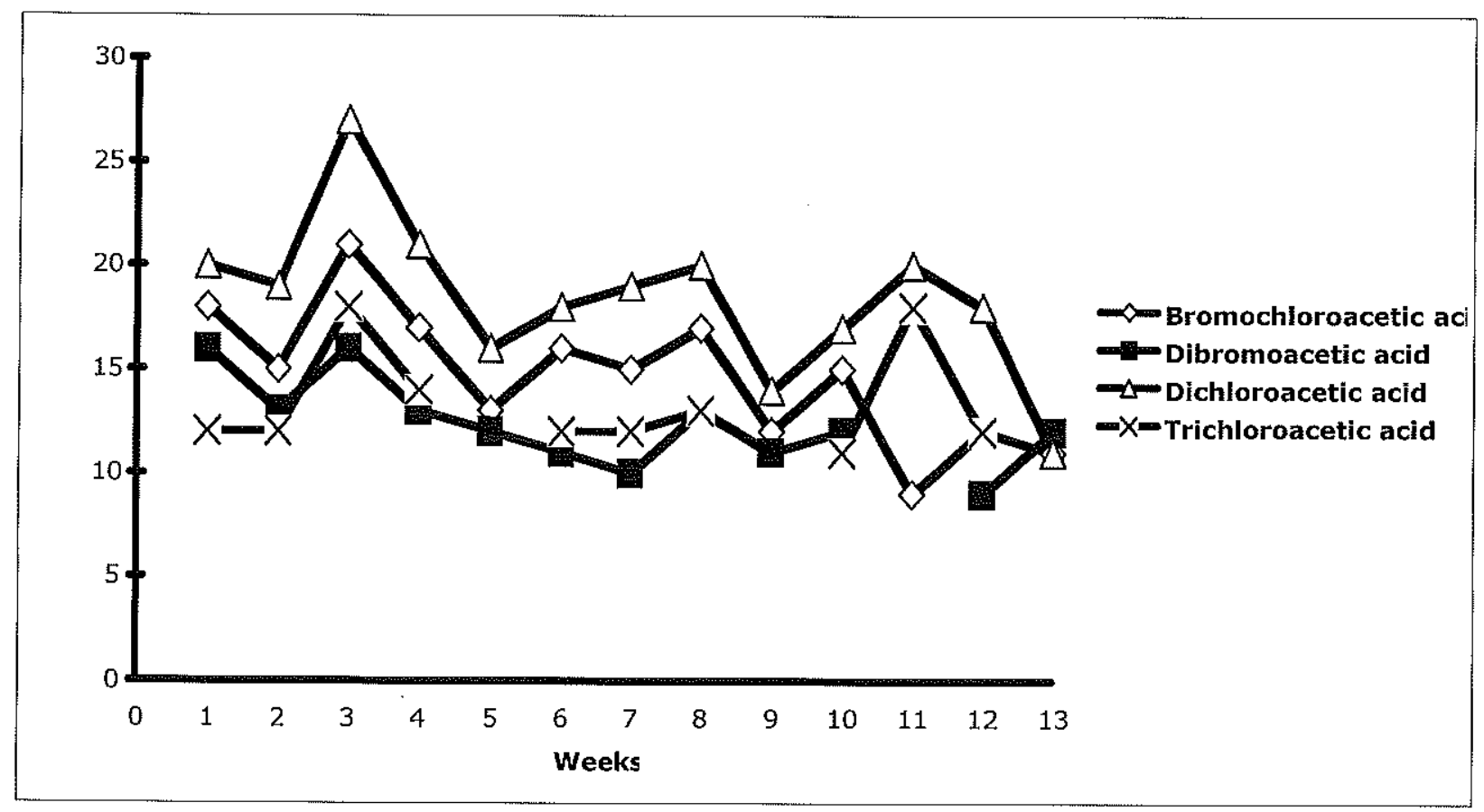

Fig. SI 1 Concentrations of haloacetic acids (HAAs) $\left(\mu \mathrm{gl}^{-1}\right)$ in treated potable water samples collected weekly for 13 consecutive weeks. Missing points indicate samples where concentration was below detection limit. For chloroacetic acid and bromoacetic acid, concentrations in all samples were below detection limit.

Table SI 1 Spearman's rank correlation between 2,2-Dichloropropionate and HAAs in treated water samples from the 13-week sampling program. None of the coefficients are significant at the $\mathrm{P}<0.01$ level. $^{23}$

DBP 1

Dibromoacetic Acid

Bromochloroacetic Acid

Dichloroacetic Acid

Trichloroacetic Acid
DBP 2

2,2-Dichloropropionate

2,2-Dichloropropionate

2,2-Dichloropropionate

2,2-Dichloropropionate

\section{Coefficient}

0.54

0.59

0.51

0.35 
Tables SI 2 and 3 Operating conditions for sample concentrator and autosampler in THM analysis. 
$\therefore$ 